\title{
Contemporary Social Work: an Analysis based on the federal budget
}

\author{
Janaina Albuquerque de Camargo Schmidt \\ Universidade Estadual do Rio de Janeiro (UERJ)
}

\author{
Mossicléía Mendes da Silva \\ Universidade Estadual do Rio de Janeiro (UERJ)
}

\section{Contemporary Social Work: an Analysis based on the federal budget}

Abstract: This study presents a critical reflection about Social Assistance policy, based on considerations about funds allocated to this policy in the federal budget highlighting the years of 2005, a landmark for the establishment of the Single Social Assistance System (SUAS) and 2013, the last year for which data are available. Data from the General Controllers Office were used to obtain indicators of federal government investments in the field. The amounts were adjusted for inflation using the General Price Index, Internal Availability, provided by the Fundação Getúlio Vargas (IGP-DI/FGV). Finally, the study shows the current trends in social assistance programs, indicating the prevalence of income transfer programs to fight extreme poverty in a large context of state commitment to financial capital.

Keywords: Social Assistance. Income Transfer Programs. Federal Budget. 


\section{Introduction}

Since the decade of 2000, Social Assistance Policy has assumed a central role in government strategies, particularly in the execution of the Brazil without Poverty Plan, created in the first term of President Dilma Rousseff and in vigor since June 2011. The plan is focused on eliminating extreme poverty in the country, as indicated by Castro and Schmidt (2012). Countless studies have demonstrated the significant importance of this policy, and the real growth in budget allocations made to it, mainly at the federal level.

The expansion of the policy in question has proved to be very important, in terms of its legitimation as a public policy that is a responsibility of the state, and includes legal-normative advances towards the constitution of a new institutional framework, based on an intense process of regulating the field. The approval of the National Social Assistance Plan ${ }^{1}$ (PNAS, 2004), of the Basic Operating Norm of the Single Social Assistance System $^{2}$ (NOB-Suas, 2005, 2012) and of the Basic Operational Norm for Human Resources ${ }^{3}$ (NOB-RH/ SUAS, 2010) are significant indications of the "administrative shock" (BEHRING, 2011, p. 86) realized in the country's Social Assistance Policy.

This expansion, however, led to a series of contradictions ${ }^{4}$ in that the unquestioned advance of the Social Assistance Policy takes place in detriment to other social security policies, and even because of the prevalence of income transfer programs at the heart of the SUAS social assistance policies.

Bibliographic research was used in the construction of this article, based on important authors who discuss the Social Assistance Policy, as well as a study of the indicators related to the budget allocations for the policy. Data were obtained from the Controladoria Geral da União (CGU) [federal General Controllers Office] from the budgets for 2005-2013, focusing on allocations, execution of allocations by function and subfunction (BRASIL, 2014 and 2014a). The SUAS was established in 2005, triggering important changes in the context of management and operationalization of the Social Assistance Policy in Brazil, as indicated in NOB/Suas of 2005 and 2012. The year 2013 was selected because it is the most recent for which data about actual spending is available. The data for the period studied were adjusted for inflation based on IGP-DI/FGV (FGV, 2014).

This article was organized primarily to present contemporary trends in the Brazilian Social Assistance Policy and then consider the budget allocations for this policy, to critically analyze the issue.

\section{Contemporary Social Assistance Policy: some theoretical considerations}

The implementation of SUAS is a fundamental mark in the regulation of the Social Assistance Policy and is crucial for its recognition as a public policy for social protection. The result of a broad socio-historic construction process, the SUAS seeks to establish a decentralized management standard that goes beyond the centralization, fragmentation and discontinuity that had historically marked Brazilian social assistance policy.

The need to establish a management system is a need that has been acknowledged since the approval of the LOAS, ${ }^{5}$ five years after its recognition as part of Brazilian Social Security, in the federal constitution.

It is important to highlight the instruments for management of SUAS that provide advances in terms of organization and technical and financial planning in the three administrative spheres: that of elaboration of the Social Assistance Plan; budgeting; monitoring, evaluation and management of information; and drafting of the annual management report (NOB-SUAS, 2013).

According to Boschetti, Teixeira and Salvador (2013, p. 2), 20 after the approval of the LOAS, the implementation of SUAS began to offer a series of important innovations and advances:

From the perspective of the conception of social assistance, it is undeniable that the institutional nature of SUAS is an attempt to remove social assistance from the framework of philanthropy and create guidelines, criteria and a strong legal framework, which were previously inexistent, and difficult to organize in a federated country, with strong national and local disparities. The conceptual definition of assistance as social protection policy present in the PNAS and in the SUAS expands the features and functions determined there, breaking with the historic nomenclature existing until then.

Nevertheless, although this new theoretical-normative framework involves a series of important changes, it is not free from introducing and or reproducing conservative concepts. Moreover, there is no debate that embraces the most fundamental determinations of poverty and social inequality as social structures, whose fundamental contradiction is located in the class struggle. According to Behring (2010a, p. 168): 
The situational analysis of the PNAS begins with the population in general and not from a fundamental determination of the insertion in the world of labor, which implies certain living conditions and the configuration of needs, in a logic in which the access to goods and services socially produced in the market depends on the sale of the force of labor by the majority. (...) The perspective of the situational analysis is that of income related to land, not labor, and through which social protection is not considered as a broad system related to other security policies, particularly those regarding social welfare.

Boschetti (2005) emphasizes that to be able to materialize the concept of social assistance in forms of basic social protection and special social protection (of middle and high complexities) requires that these forms of protection be located in the set of protections called for by social security. This is thus an indispensable condition for not making the mistake of conceiving and operationalizing social assistance policy in a manner that is not articulated to other policies that compose social security. If this does not happen, the mistake can be made of identifying it as doted of exclusivity and understand that on its own it could address the countless situations that the expressions of the social question impose on interventionist state forms. In this sense, Boschetti (2005, p. 13) indicates that in the implementation of basic social protection, "it is a challenge of the SUAS to seek articulation with guaranteed social protection for health care, welfare and other public policies, to establish general and preventive programs."

This brief explanation of the advances and limits of the Social Assistance Policy allows inferring that these processes are realized at the interior of a broader movement, whose determinations are rooted in current social transformations. The entire regulatory apparatus of the politics in focus results from the intense struggles that challenge it and make dynamic the format and place that social assistance occupies in the field of Brazilian social protection. That is, the social direction mentioned is in constant dispute by antagonistic social projects. We can thus say that there are fields of resistance, but the current content points to the preponderance of a conservative project that has conferred to social assistance a clear selective perspective, which is focused, assistance-oriented and philanthropic.

Social Assistance programs have been sharply increased, but with a selective and focused nature. More specifically, since the Lula government, there has been a broad investment in policies for fighting poverty, assuming global trends recommended by multilateral agencies, with a clear focus on income transfer programs.

The perspective for confronting poverty was the main orientation of Lula's electoral campaigns and of his administrations, a perspective that remains in the government policy of President Dilma. Meanwhile, there has been a continuity of the neoliberal project, and therefore, benefits to capital - particularly to financial capital - found in the form of the government's primary surpluses and other budget artifices. In this light, it should be noted that in recent years, neoliberal policy has led to an exacerbation of poverty, which has thus come to stand out as an object of intervention, considering the economic, social and political risks it presents. It is evident that the Worker's Party governments have not followed a direct line of continuity with the previous government of Fernando Henrique Cardoso. The maintenance of an economic stability policy, which emphasizes fiscal adjustment and monetary stability, is combined with new forms of intervention in the social question, which are elucidated by the assistance programs for the alleviation of poverty. (ALVES, 2013).

This configuration of social protection, based on compensatory residual, focused and selective social policies, is the standard of state intervention in social questions, compatible with the current needs for the accumulation of capital.

The current context does not constitute a post-liberal era, but shares a series of new determinations that have been problematized, which some authors characterize as "neodevelopmentalist" (SICSÚ; PAULA; MICHEL, 2005). Neodevelopmentalism embodies a series of contradictions, and has been an object of important debate and intense Marxist criticism. Important contributions, with a critical perspective, emphasize that this "governmental programmatic" does not assure a new level of development, but has served to support interests of the dominant fractions of capitalism. As a governability strategy, it is based on the following tripod: state incentives to the oligopolization of the economy (through the strengthening of large private economic groups with support from the BNDES); public investments in infrastructure - with or without a public-private partnership; and state income transfer programs (grants, minimum wages and salary formalization), seeking to strengthen the domestic consumer market (ALVES, 2013). 
In parallel to maintaining commitments to financial capital, the Social Assistance Policy is based mostly on income transfer programs designed to minimize the most damaging effects of the destructive advances of contemporary capitalism. Discourses about fighting poverty become central to establishing a consensus around the current project:

\begin{abstract}
The increasingly privileged space that poverty assumes in the debate about social policy causes the forms assumed for confronting the social question to impede the generalization of social rights. The problem is not only in the priority of poverty as a category of analysis for considering social policies, but in the form and treatment given to the "poor," which are renowned for their fragilities, decontextualized and dehistoricized, appearing in the reconstituted technocratic discourse under a new type of moral vigilance (MAURIEL, 2012, p. 181).
\end{abstract}

This has important implications for Social Assistance Policy, to the degree to which its priority is to confront poverty. According to Mauriel (2012, p. 189), the late institutionalization of the Social Assistance Policy takes place in an environment in which the intervention in the social question, which concentrates on a focalized combat of poverty, "deepens the process of symbolic and ideological deconstruction of security as a basis for considering and constructing social policies, impeding precisely the intersectorial character that this policy should have with the other public policies."

In this direction, Mota's (2008) analysis is important because it emphasizes that the guidelines and organization of the contemporary Social Assistance Policy indicate that the right to social assistance increasingly assumes the role of providing "integration," to society, substituting the right to work. In this way, it appears not only as the legally instituted form of handling those who are "excluded" from the labor market, but also of keeping them active in the sphere of consumption, assuming a social function in the reproduction of the labor force.

Thus, it can be pointed out that this expansion, despite the advances, has legitimated itself through a logic that is in opposition to the principles of the federal Constitution of 1988, whose perspective signaled the possibility of a universalizing social security system. What has been revealed is "a contradictory unit [in the realm of] Brazilian social security." We have witnessed the privatization of healthcare and social welfare and the construction of the logic of the "citizen-consumer" as well as the "centrality of Social Assistance" (MOTA, 2008, p. 133). Moreover, the centrality of this policy in relation to others, which compose social security, as well as the uncontested expansion of its resources, is realized not by an expressive investment in the consolidation of a network of universal and quality public social-assistance services, but through the prevalence of the income transfer programs. Despite their impact on the general framework of poverty in the country, these programs have concretized a type of duality in which is found on one hand, a deficient SUAS, and its various social-assistance services and, on the other, the transfer of benefits directly to the citizen, particularly through the Family Grant Program.

When social assistance is expanded by means of the quantitative expansion of the Family Grant Program in detriment to SUAS itself, or of the network of services that it supposes and requires, a series of implications imposes serious restrictions to the consolidation of the SUAS:

There are not enough funds for application in the services network, [for] constructing organized and quality public facilities, references in the municipal plans and in the territories, [for] assuring working conditions to the Social Assistance workers, confidential services, or professional autonomy in the technical procedures, going beyond the basic service, preferably with decent salaries (BEHRING, 2011, p. 90)

This configuration of social protection, based on compensatory residual, focused and selective social policies, is the standard of state intervention in social questions, compatible with the current needs for the accumulation of capital. In other words, there is a general debility of universal and permanent policies and priority is given to assistance programs.

By problematizing the prevalence of the income transfer programs to the detriment of the SUAS we are not affirming that SUAS would be able to resolve the problems resulting from poverty, social inequality, structural unemployment and the precariousness of labor. The intention is to discuss how social assistance is focused on income transfer programs in detriment to expanding investment in other social policies, including SUAS itself. We also highlight that this process is broadly determined by the concrete fact that a significant part of the budget for social policies is appropriated by large capital, particularly financial capital.

It is necessary to clarify that the income transfer programs, above all the Family Grant Program, are an objective need, given the current context of structural unemployment. But their meager benefits, their conditionality strategy, as well as their still fragile structure for social control, increasingly require studies that demystify the ideological apparatus that cloaks a program with effective impact on the population's living conditions. 


\section{Analysis of Social Assistance Policy: a focus on the government budget}

We present a analysis of some indicators of changes in public spending for Social Assistance to problematize contemporary trends in public investment in this policy and consequently the economic-political direction in which it is implemented in Brazil. In this regard, we agree with Salvador (2010, p.172) when we affirm that the public budget is not simply a technical mechanism but a field of political struggle of distinct social forces defending their interests. It is very important to understand the trends of social policies, given that the budget priorities reflect "the correlation of social forces and the interests involved in the appropriation of public resources, as well as the definition of who will bear the burden of financing budget expenditures."

The data comes from the CGU and is adjusted for inflation using the IGP-DI/FGV. Graph 1 presents a relationship between the Social Assistance Policy and the total federal government spending including social security):

\section{Graph 1: Social Assistance government spending including social security}

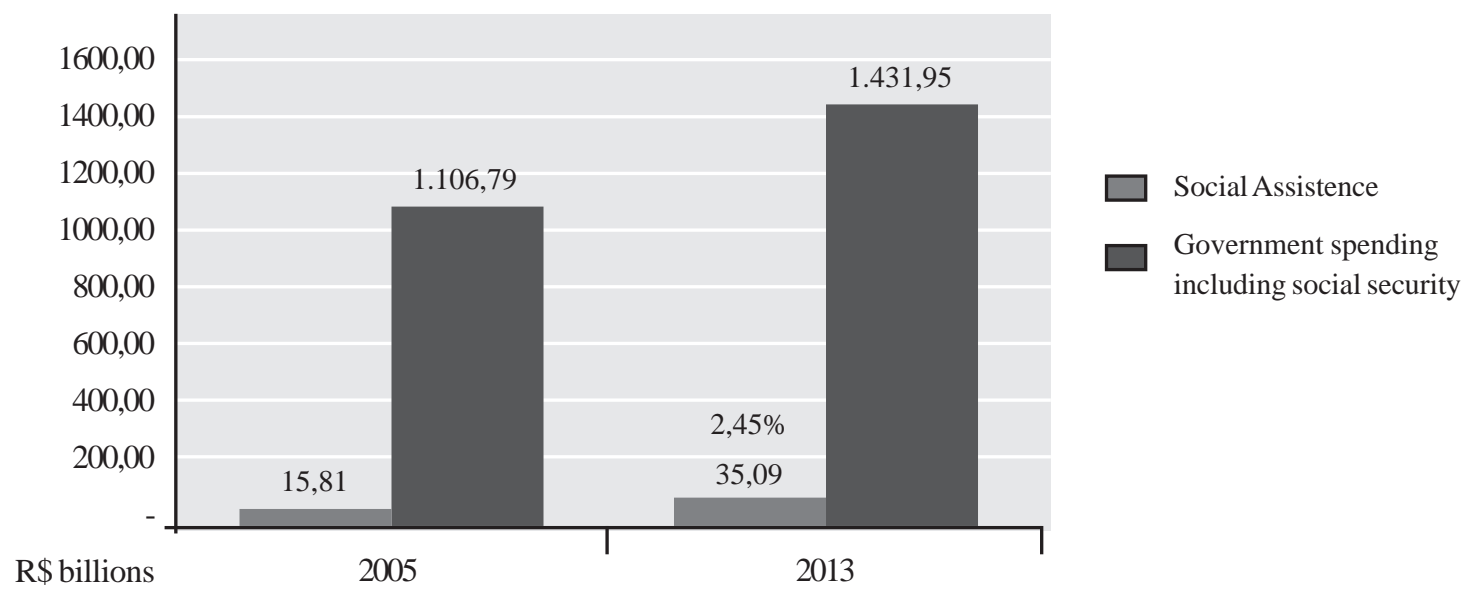

Source: CGU. Graph prepared by the author. Period up to 2013 adjusted for inflation using (IGP-DI/FGV).

Based on the data presented in Graph 1, an important change in government spending on social assistance can be seen in each year. In 2005, the percent of government spending (including social security) spent on social assistance was $1.43 \%$, rising to $2.45 \%$ in 2013 . We can identify a $122 \%$ increase of public investments in social assistance from $2005-2013$. These considerations are important, considering the subaltern history of social assistance among the public policies.

It is important to emphasize a fact that is not found in the graph, but is reflected in the Social Assistance Policy and in other public policies: the federal government's spending on debt, mainly domestic debt. The resources aimed at debt payments ${ }^{6}$ in 2005 were nearly $\mathrm{R} \$ 638$ billion, given that the domestic debt occupied $94.4 \%$ of this amount. This indicates that $57.7 \%$ of the total federal budget including social security was spent on debt payments, compared with $1.43 \%$ for social assistance. In 2013, some R $\$ 718$ billion was spent (or $\mathrm{R} \$ 670$ billion in inflation adjusted 2005 values,) and internal debt occupied $95.2 \%$ of this amount. Once again, when the "total" debt is compared with the government spending including social security it is found that $46.8 \%$ was spent on debt and $2.35 \%$ on social assistance. Although the proportion of public spending on debt has decreased, it is still considerably higher than what is spent on social assistance and other public policies.

This analysis shows that the state action is more dedicated to favoring financial capital and less to implementation of government social policies, a tendency demonstrated in the study by Salvador (2010, p. 44), which affirms that "resources that should be applied to social policies [are directed] to the payment of the Brazilian government debt, whose creditors are the rentiers of financial capital."

The government debt has been one of the main mechanisms for the effective transfer of wealth from public funds to financial capital. According to Behring (2010b, p. 20-21), the public fund is composed of resources from surplus labor and necessary labor "in the form of taxes, contributions and fees." To the degree to which our tax burden is mostly composed of indirect taxes, the working class has been "contributing" more decisively to the "public fund," the government budget. 
In the current regime of accumulation, government spending is vital to the reproduction of the labor force and capital. In this way, the social struggles concerning its destination are increasingly tense and this scenario has demonstrated that, despite the struggles over social rights, the bourgeoisie - particularly its financial fraction - have more favorable conditions to appropriate public resources, for which the mechanism of the public debt is essential.

The graph below compares Social Assistance with the selected policies: Welfare (including resources allocated to labor policies, because it includes Unemployment Insurance) and Healthcare.

\section{Graph 2: Social Assistance in comparative perspective}

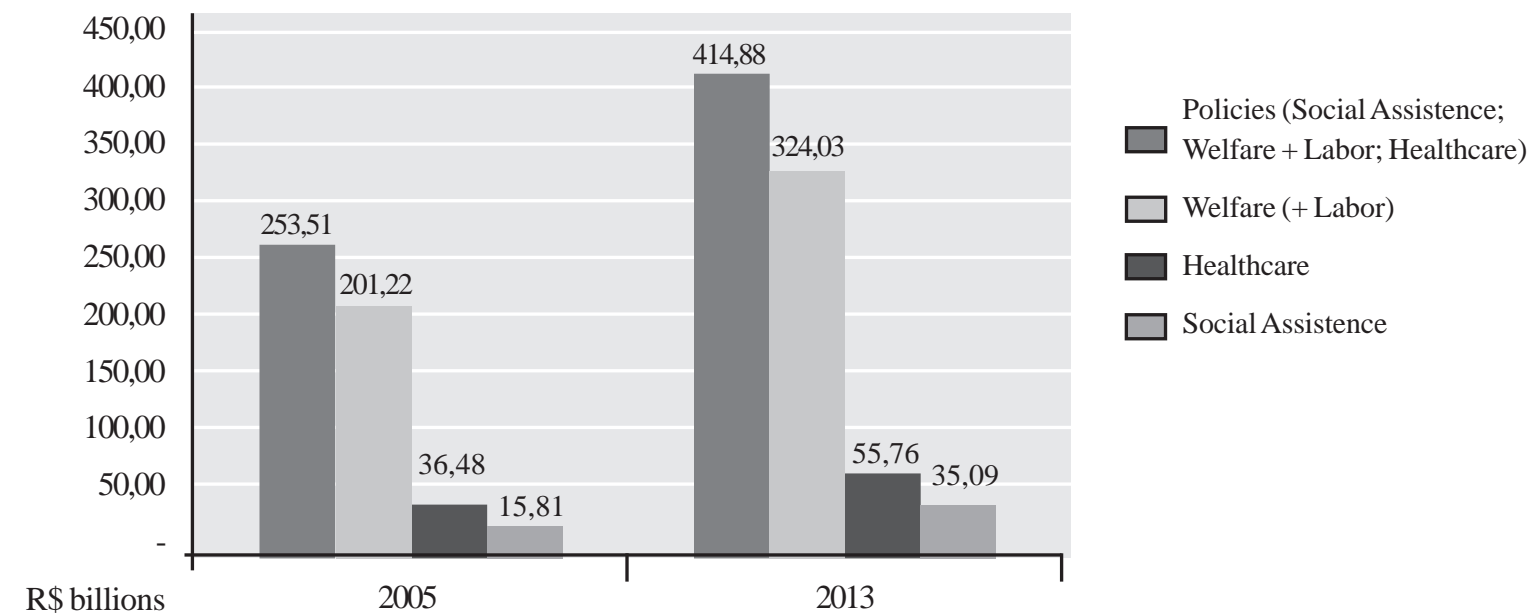

Source: CGU. Graph prepared by the author. Períod through 2013 adjusted for inflation using the (IGP-DI).

Graph 2 reveals that the destination of resources to social assistance occupied $6.2 \%$ of the total resources of the policies listed in 2005, with welfare spending (including unemployment insurance) at $79.4 \%$, and healthcare at $14.4 \%$. This configuration changed by 2013 , mainly in the comparison between social assistance and healthcare: the former received $8.5 \%$ of the total resources and the later $13.4 \%$; while welfare spending received $78.1 \%$. Note that spending on social assistance approached that of healthcare, which we attribute to the importance that social assistance policy acquired in the current political and economic scenario and in the execution of the income transfer programs - which we can see in the next graph.

It is important to affirm that even if the nominal values of the Social Assistance Policy are still lower than those of other social security policies, their rate of growth is significantly higher in the period studied. This expansion raises the need to consider the place that it has been occupying in social protection, without drawing mistaken conclusions. According to Boschetti, Teixeira and Salvador (2013, p. 4), this reflection requires being careful not to take two tempting risks: the first is "to over dimension it as a social protection policy capable of overcoming poverty and social inequality"; the second is to delegitimize it "as a public policy, that favors philanthropic understandings and practices."

Graph 3 below refers to the destination of resources of the Assistance Policy, to identify the direction of its action in Brazil.

The data indicate that a large portion of the resources allocated in the Social Assistance Policy pertain to income transfer programs, such as the Family Grant Program and the Continued Payment Benefit (CPB). The data from the CGU indicate that R \$28,2 billion was spent on Community Assistance, which includes the Family Grant Program. According to data from the government's Portal da Transparência [Transparency Portal], the federal government spent some R \$ 24,8 billion in 2013 on the Family Grant Program (BRASIL, 2014). That is, most of the resources for Community Assistance is aimed at the Family Grant Program. We thus find that the direction of the current Social Assistance Policy, with the focus on income transfer programs, focused on extreme poverty. 


\section{Graph 37: Destination of Social Assistance funds}

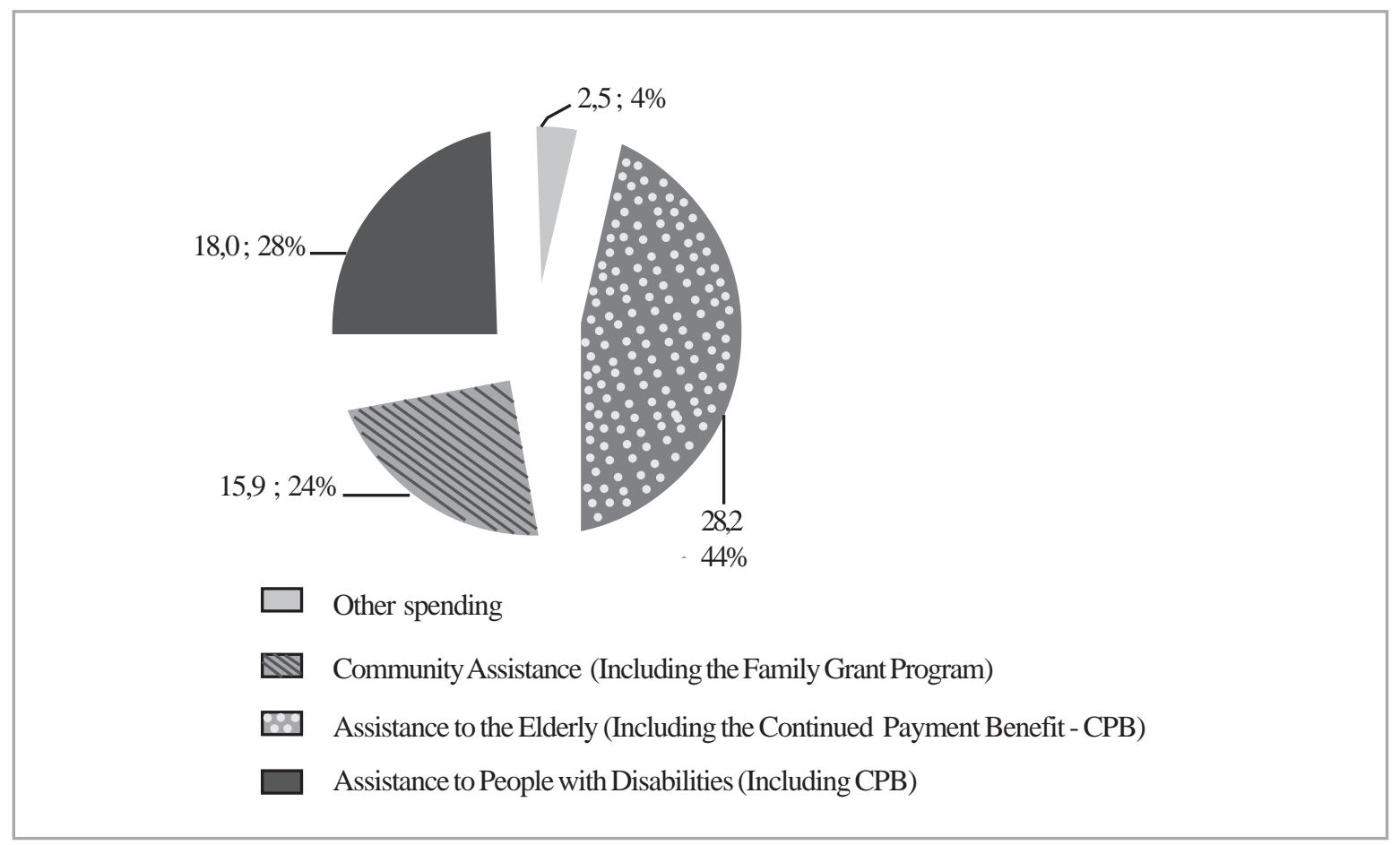

Source: CGU. Graph prepared by the authors.

The income transfer programs function to support to the current regime of accumulation, because in addition to impacting social indicators related to healthcare and education, because of the conditionalities of the policies they are of crucial importance for leveraging domestic consumption.

\section{Final considerations}

Social Assistance Policy has taken on a new level in recent decades, with important advances in its theoretical-normative scope, consolidating an important movement of regulation in the field, with innovations in the field of administration of a social policy that historically suffered from lack of recognition as a legitimate public policy. These advances are essential, but the expansion of this policy carries a series of contradictions because it has expanded in detriment to other social security policies. The kind of integration that should articulate these policies has become unviable under the current social protection model that is based on compensatory social policies, marked by focalization and selectivity.

Moreover, the prevalence of the Income Transfer Programs also raises important challenges in this field. We recognize their relevance in the mark of contemporary capitalism, considering their impact on extreme poverty; yet also recognize that these programs do not achieve a redistribution of income, and are only effective in the context of the country's structural inequality.

In this sense, greater public investment is needed to strengthen SUAS, the public network of social assistance services and the democratic public management to develop the Social Assistance Policy from a perspective of social rights, and not simply restrict it to fighting extreme poverty.

\section{References}

ALVES, G. Neodesenvolvimentismo e precarização do trabalho no Brasil. Disponível em: <http://blogdaboitempo.com.br/2013/05/20/ neodesenvolvimentismo-e-precarizacao-do-trabalho-no-brasil-parte-i/>. Acesso em: 24 ago. 2013.

BEHRING, E. R. Balanço Crítico do SUAS e o Trabalho do/a Assistente Social. In: Conselho Federal de Serviço Social. Seminário Nacional O trabalho do/a Assistente Social no SUAS. Brasília: CFESS, 2011. p. 84-95. 
Trabalho e Seguridade Social: o neoconservadorismo nas políticas sociais. In: Trabalho e Seguridade Social: percursos e dilemas. Elaine Rossetti Behring e Maria Helena Tenório de Almeida (Orgs). São Paulo: Cortez, 2010a. p. 152-174.

. Crise do capital, fundo público e valor. In: BOSCHETTI, I. et al. (Orgs.). Capitalismo em crise: política social e direitos. São Paulo: Cortez, 2010b. p.13-34.

BEHRING, E. R; BOSCHETTI, I. Política Social, fundamentos e história. São Paulo: Cortez, 2006.

BOSCHETTI, I. O SUAS e a seguridade social. In: Cadernos de Estudos Desenvolvimento Social em Debate. Suplemento. Brasília: Ministério do Desenvolvimento Social e Combate à Fome, Secretaria de Avaliação e Gestão da Informação, 2005. p. 10-16.

BOSCHETTI, I.; TEIXEIRA, S. O.; SALVADOR, E. AAssistência Social após 20 anos de LOAS: fim da travessia do deserto? In: Anais do $14^{\circ}$ Congresso Brasileiro de Assistentes Sociais. Águas de Lindóia: CFESS-CRESS/SP, 2013.

BRASIL, 2014. Controladoria Geral da União. Disponível em: 〈http://www.cgu.gov.br/publicacoes/prestacaocontaspresidente/index.asp> Acesso em: 12 ago. 2014.

BRASIL, 2014. Portal da Transparência. Transferência de recursos por ação de governo. Disponível em: <http:// www.portaltransparencia.gov.br/PortalTransparenciaPesquisaAcaoUF.asp? codigo Acao $=8442 \& \operatorname{codigoFuncao}=08 \&$ NomeAcao $=$ Transfer\%EAncia + de + Renda + Diretamente $\%$ E0s + Fam $\%$ EDlias $+e m+C o n d i \% E 7 \% E 3 o+d e+P o b r e z a+e+$ Extrema+Pobreza+\%28Lei+n\%BA+10\%2E836\%2C+de+2004\%29\&Exercicio=2013. Acesso em: 12 ago. 2014.

BRASIL, 2014a. Controladoria Geral da União. Prestação de Contas do Presidente da República (Balanço-Geral da União) e Relatório e Pareceres Prévios do TCU. Disponível em: <http://www.cgu.gov.br/Publicacoes/PrestacaoContasPresidente/2005/Volume\%202/ Parte\%20V/VOLII_0808.pdf $>$. Acesso em: 12 ago. 2014.

BRASIL, Conselho Nacional de Assistência Social. RESOLUÇÃO N. ${ }^{\circ} 33$, de 12 de Dezembro de 2012. Aprova a Norma Operacional Básica do Sistema Único de Assistência Social -NOB/SUAS. Diário Oficial da União. 03 de Janeiro de 2013.

BRASIL. Lei 12.435, de 6 de julho de 2011. Altera a Lei no 8.742, de 7 de dezembro de 1993, que dispõe sobre a organização da Assistência Social. Disponível em: <http://www.planalto.gov.br/ccivil_03/_Ato2011-2014/2011/Lei/L12435.htm>. Acesso em: 12 ago. 2014.

BRASIL. Lei $n^{\circ}$ 8.742, de 7 de dezembro de 1993. Dispõe sobre a organização da Assistência Social e dá outras providências. Disponível em: <http://www.planalto.gov.br/ccivil_03/leis/18742.htm>. Acesso em: 12 ago. 2014.

BRASIL. Ministério do Desenvolvimento Social e Combate à Fome. Secretaria Nacional de Assistência Social. Norma Operacional Básica - NOB/SUAS: construindo as bases para a implantação do Sistema Único de Assistência Social. Brasília: Ministério do Desenvolvimento Social e Combate à Fome, Secretaria Nacional de Assistência Social, 2005.

BRASIL. Ministério do Desenvolvimento Social e Combate à Fome. Secretaria Nacional de Assistência Social. Norma Operacional Básica de Recursos Humanos do SUAS - NOB-RH/SUAS. Resolução nº 269/2006 do Conselho Nacional de Assistência Social. Brasília: Ministério do Desenvolvimento Social e Combate à Fome, Secretaria Nacional de Assistência Social, 2010.

BRASIL. Resolução n 145/2004 do Conselho Nacional de Assistência Social. Política Nacional de Assistência Social (PNAS). Brasília: Ministério do Desenvolvimento Social e Combate à Fome, 2005.

CASTRO, A. T. B. de; SCHMIDT, J. A. de C. O Plano Brasil sem Miséria e a Política de Assistência Social no foco da crítica. Anais do XIII ENPESS - Encontro Nacional de Pesquisadores em Serviço Social. UFJF: Juiz de Fora/MG, Novembro de 2012.

FGV. Fundação Getúlio Vargas. Índice Geral de Preços: Disponibilidade Interna - IGP-DI. Disponível em <http://www.portalbrasil.net/ igp.htm>. Acesso em: 14 ago. 2014.

MAURIEL, A. P. O. Pobreza, seguridade e Assistência Social: desafios da política social brasileira. In: Desenvolvimentismo e construção de hegemonia: crescimento econômico e reprodução da desigualdade. Ana Elizabete Mota (Org.). Recife: Ed. Universitária da UFPE, 2012.

MOTA, A. E. A centralidade da assistência social na Seguridade Social brasileira nos anos 2000. In: O mito da assistência social: ensaios sobre Estado, Política e Sociedade. Ana Elizabete Mota (Org.). São Paulo: Cortez, 2008. p. 133-146.

SALVADOR, E. Fundo público e seguridade social no Brasil. São Paulo: Cortez, 2010.

SICSÚ, J.; PAULA, L. F. de; MICHEL, R. Por que novo desenvolvimentismo? In: nacional de crescimento com equidade social. São Paulo: Manole, 2005.

Novo desenvolvimentismo: um projeto

\section{Notas}

1 Resolução no 145/2004 do Conselho Nacional de Assistência Social [National Social Assistance Council]. The PNAS/2004 reaffirmed the principles inscribed in the Lei Orgânica de Assistência Social (Loas) [The Instrumental Social Assistance Law], which defined principles and guidelines for the implementation of SUAS, establishing a new perspective for the organization and management of Brazilian Social Assistance.

2 Resolução n ${ }^{\circ}$ 130/2005 do Conselho Nacional de Assistência Social. The NOB/Suas regulates the administration of the Social Assistance Policy, according to the Federal Constitution of 1988, the LOAS and complementary legislation. It governs, among other issues: the division of competencies and responsibilities among the three spheres of government; the administrative levels of each one of the spheres; the agencies involved in the management and control of this policy and how they are related; the new relationship between the agencies and governmental and non-governmental organizations; the principal management instruments to be used; and the form of financial management, which consider the 
mechanisms for transfer, the criteria for allocations and the transfer of resources (NOB-SUAS, 2005, p. 14).

3 Defines principles and guidelines for the management of work, with indications of Job and Career Plans, training guidelines, and the responsibilities of government administrators in different agencies.

4 Social policy embodies a set of contradictions related to its role in capitalist society, concerning the fundamental contradiction of the capital-labor relationship. Thus, as state mechanisms for intervention in the expressions of the "social question," social policy contradictorily serves the interests of the working class and of capital. It is the result of the social struggles that are established between the social classes and therefore are determined by the correlation of forces present in society (BEHRING; BOSCHETTI, 2006).

5 Lei [Law n. $^{\circ}$ 8.742/1993. On 6, July, 2011 Lei n. ${ }^{\circ} 12.435$ was sanctioned, altering Lei $n .{ }^{\circ}$ 8.742. The new language of the LOAS ratified the implementation of an administrative system for the Social Assistance policy and inserted the Single Social Assistance System within it.

6 The CGU site presented the following data related to the debt: internal debt refinancing; refinancing of the foreign debt; internal debt service; foreign debt service.

7 The values in Graph 3 were not adjusted for inflation, because this is not a historic series, only the amounts informed for allocations in 2013.

\section{Janaina Albuquerque de Camargo Schmidt}

janaina.camargo@uol.com.br

Doutoranda do Programa de Pós-Graduação em Serviço Social da Universidade Estadual do Rio de Janeiro (UERJ).

\section{Mossicléía Mendes da Silva}

mossi_c@yahoo.com.br

Doutoranda do Programa de Pós-Graduação em Serviço Social da Universidade Estadual do Rio de Janeiro (UERJ).

\section{UERJ}

Campus Maracanã

Rua São Francisco Xavier, 524 - Pavilhão João Lyra Filho, Bloco D, sala 9002

Maracanã

Rio de Janeiro - Rio de Janeiro - Brasil

CEP: 20550-013 